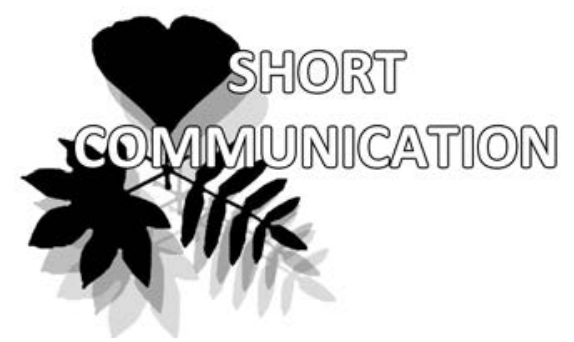

\title{
Low variability of Orchis militaris L. in a local population in the Altay Territory, Russia: evidence from morphometrical and caryological analyses
}

\author{
Yulianna G. Zaytseva*, Alexandra Yu. Nabieva \& Elena V. Zhmud
}

Yulianna G. Zaytseva*

e-mail: ulianna_zaitseva@mail.ru

Alexandra Yu. Nabieva

e-mail: sibflower@gmail.com

Elena V. Zhmud

e-mail: elenazhmu@gmail.com

Central Siberian Botanical Garden SB RAS Novosibirsk, Russia

* corresponding author

Manuscript received: 28.05.2021

Review completed: 29.10 .2021

Accepted for publication: 10.11 .2021

Published online: 12.11.2021

\begin{abstract}
A B S T R A C T
Orchis militaris L. is a rare species at the territory of Russia and in many of its regions. This species has been studied for a long time, but the genome size of its representatives in natural conditions has not been studied yet. This assessment is of great importance for the development of measures for the rare species preservation in natural conditions and in the tissue culture. Chromosome counts were completed by flow cytometric data and morphological observations in order to study the species intrapopulation variability. Here, the flow cytometric data on genome size and DNA content of O. militaris from the Asian part of Russia are presented for the first time.
\end{abstract}

Keywords: genome size, DNA content, flow cytometry, variability, Orchis militaris L.

\section{P E 3 Ю M E}

Зайцева Ю.Г.*, Набиева А.Ю., Жмудь Е.В. Низкая вариабельность Orchis militaris L. в мокацьной попумяции в А^тайском крае (Россия) по Аанным морфометрического и кариомогического анамиза. Orchis militaris L. известен как редкий виА на территории России и многих её регионов. Несмотря на Аавнюю историю изучения виАа, размер генома у его представителей в природных условиях на территории России до сих пор не изучен. Эта оценка имеет важное значение Аля разработки мер сохранения вида в природных условиях и в культуре in vitro. С целью изучения внутрипопуляционной изменчивости виАа ПоАсчет хромосом был АОПолнен Аанными проточной цитометрии и морфологических наблюАений. В Аанном сообщении мы впервые представляем данные о размере генома и содержании $А Н К$ у растений O. militaris из азиатской части России, полученные с помощью метода проточной цитометрии.

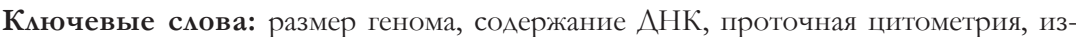
менчивость, Orchis militaris L.
Orchis militaris L. (Orchidaceae) is included in Annex II of the CITES International Convention and is listed as rare with the status 3c (rare species) in the Red Books of Russia and the Altay Territory (Trutnev 2008). The study of individuals in local populations is an important part of determining the status of a species in nature. This information is especially relevant for the rare species $O$. militaris. This is a taxon with a small number of individuals; in a limited area, it occurs or is distributed sporadically over large areas. For the survival of such species, special protection measures are needed.

Analysis of nuclear DNA content using flow cytometry proved to be a useful method for rapid orchid species identification and studying of intrapopulation variability. It is relatively cheaper compared to the molecular methods. Genome size data for orchids growing wild are often limited to their European populations (Jacquemyn et al. 2012), so far studies concerning $O$. militaris have been carried out in Eastern Europe (Rewers et al. 2021). Information on genome size in O. militaris in Russia has not been reported yet, and the data obtained from European populations could not be taken into consideration to describe the species po- pulations from the Asiatic part of Russia, whereas endopolyploidy and natural interspecific hybridization are quite common among the members of Orchidaceae family. O. militaris genome uniformity data from geographically isolated local population (LP) are lacking as well as the species morphological characters analysis. Therefore, the aim of this study was to estimate the variability of genome size, chromosome number and morphometric parameters of O. militaris individials from the Altay Territory population.

Sampling was conducted in 2019 in local population $\left(51.502320^{\circ} \mathrm{N} 84.613548^{\circ} \mathrm{E}\right)$ near the settlement Soloneshnoe, the administrative center of Soloneshensky District of the Altay Territory of Russia. Nine plants were used for caryological and morphometric estimations.

To determine relative DNA content and genome size in O. militaris specimen, grown in the natural LP, flow cytometry (FCM) analysis with CyFlow ${ }^{\circledR}$ Space (Partec, Germany) was performed. For calculating the relative DNA content of the test samples, Pisum sativum L. 'Ctirad' (2C $=9.09 \mathrm{pg})$ was used as a reference standards with a known DNA content (Doležel et al. 1998). The nuclei extraction and sample preparation were carried out according to manufacturer protocol 
with the use of $1 \%$ polyvinylpyrrolidone (Sigma-Aldrich, USA). The nuclei were stained by the buffer containing propidium iodide (PI) and RNAse. To determine relative DNA fluorescence, the samples were analyzed by means of FCM using a green laser $(532 \mathrm{~nm})$ at $30-50$ events per minute. DNA content and genome size were calculated using the standard formulas (Doležel et al. 2003, 2007). The DNA content data were evaluated with FloMax 2.9 software package (Partec, Germany).

Chromosome preparations of mitotic states were made from root tips, as described by Krasnikov (2004). The prepared slides were observed with the Axioskop-40 imaging (Carl Zeiss) microscope and photographed with the AxioCam MRc5 high-resolution digital camera, using AxioVision 4.8 digital image processing software.

All experiments consisted of three independent replicates. Variability of the morphological characters of O. militaris specimen was analyzed using MS Excel. The morphological characters variation was estimated according to Zaitsev's criteria (1984).

The study of chromosome numbers, genome sizes and morphological characteristics allows creating a basis for the preservation of all components of the species biodiversity and its introduction into culture. Unfortunately, morphometric data and chromosome counting are often missing in orchids genome variability studies (Rewers et al. 2021). Chromosome preparations of O. militaris reported from European wild populations showed that the species had a stable number of chromosomes $2 n=42$ (Farrel 1985, Vakhrameyeva et al. 1995). Our own chromosome counting among $O$. militaris individuals from the studied LP comprised only diploids, and determination of the species ploidy level by means of FCM successfully approved these findings.

Table 1. Relative DNA content and genome size of Orchis militaris representatives from a local population (Altay Territory, Russia).

\begin{tabular}{lccc}
\hline No of sample & 2C, pg & 1C, pg & Genome size, Mbp \\
\hline 1 & 22.88 & 11.44 & 11186.88 \\
2 & 23.32 & 11.66 & 11403.86 \\
3 & 23.20 & 11.60 & 11346.47 \\
4 & 22.56 & 11.28 & 11029.65 \\
5 & 22.97 & 11.49 & 11232.66 \\
6 & 23.33 & 11.66 & 11406.06 \\
7 & 24.12 & 12.06 & 11794.52 \\
8 & 22.73 & 11.36 & 11112.53 \\
9 & 24.06 & 12.03 & 11763.76 \\
\hline Mean & 23.24 & 11.62 & 11366.24 \\
\hline Standard error (SE) & 0.18 & 0.09 & 101.10 \\
\hline
\end{tabular}

2C - diploid DNA content, pg; 1C - haploid DNA content, pg; Mbp - Mega base pairs

Table 2. Variations in morphological features of Orchis militaris in a local population (Altay Territory, Russia).

\begin{tabular}{lcc}
\hline Characters & Mean士Standard error & Variation, $\%$ \\
\hline Height of the plant, cm & $20.4 \pm 2.5$ & 39.3 \\
Inflorescence length, cm & $10.1 \pm 3.2$ & 93.5 \\
Number of flowers & $20.5 \pm 2.8$ & 42.5 \\
Number of leaves & $4.1 \pm 0.2$ & 18 \\
Length of the second lowermost leaf, cm & $11.0 \pm 1.2$ & 35.4 \\
Width of the second leaf, cm & $3.7 \pm 0.2$ & 17.5 \\
\hline
\end{tabular}

The FCM profiles indicated homogeneity of the ploidy level in leaf cells of the samples. Relative genome sizes (2C) of the genotypes ranged between $22.56 \mathrm{pg}$ and $24.12 \mathrm{pg}$, consequently $1 \mathrm{C}$ varied from 11.28 to $12.06 \mathrm{pg}$, an average $23.24 \mathrm{pg}$ and $11697.39 \mathrm{Mbp}$, respectively (Table 1). As it is known, Orchidaceae are characterized by a wide range of the genome size, varying from 0.66 to $110.8 \mathrm{pg} / 2 \mathrm{C}$ (Leutch et al. 2009). The obtained data correspond to the intermediate genome size according to Soltis et al. (2003).

According to our studies, the genome size in the studied O. militaris individuals was relatively intermediate (an average $23.24 \mathrm{pg}$ ). This result is consistent with the data obtained for the representatives of the species in East Europe (Rewers et al. 2021), which indicates the stability of the genome of this species despite the geographical isolation of its populations.

Data on morphometric characters variation in O. militaris in Russia are scarce. We carried out a comparative morphometric analysis of $O$. militaris representatives from LP in the Altay Territory with the specimen described from the northern part of the range, South Yakutia (SY) (Afanaseva 2011). The analysis of the mean values and variability of six morphometric characters in the LP of $O$. militaris showed that the data on the studied characters are consistent with the literature data for the species studied in the northern part of the range, South Yakutia (SY) (Afanaseva 2011). Mean values of morphometric characters in different parts of the range did not differ significantly. Variations in most of the studied characters within normal limits were noted (5-44\%) (Table 2). At the same time, according to our data, the inflorescence length varied over a very large range. This fact is consistent with the data of Shamigulova (2012).

The analyses of morphometric and genome size data provide evidence for a clear pattern of diploidy for O. militaris across all samples from the LP from Altay Territory. In the studied O. militaris CP low morphological differentiation in terms of size and quantitative characters was supported by a low degree of genome size variability using flow cytometry and direct chromosome counting, which showed an invariable diploid chromosome number. Thus, O. militaris genome stability, studied for the first time among the representatives from the remote part of its range, was approved. It can be assumed that the low variability of all studied characteristics determines the vulnerability of the species.

\section{ACKNOWLEDGEMENTS}

The aim of this work was fulfilled with the financial support of the budget project "Analysis of biodiversity, conservation and restoration of rare and resource plant species using experimental methods" No. AAAA-A21-121011290025-2 within the framework of the State Assignment. 


\section{LITERATURE CITED}

Afanaseva, E.A. 2011. Population status of Orchis militaris L. (Orchidaceae) in Southern Yakutia. In: Conservation and cultivation of orchids. Materialy IX Mezhdunarodnoi konferentsii (26 - 30 sentyabrya 2011). (I.I. Shamrov, ed.), pp. 35-38 KMK, Moscow (in Russian). [Афанасьева Е.А. Состояние ценопопуляций Orchis militaris L. (Orchidaceae) в Южной Якутии. Охрана и культивирование орхидей. Материалы IX МежАународной конференции (26 - 30 сентября 2011 г.) / под реА. И.И. Шамрова. М.: КМК - Товарищество научных изАаний. С. 35-38].

Doležel, J., J. Bartoš, H. Voglmayr \& J. Greilhuber 2003. Nuclear DNA content and genome size of trout and human. Cytometry 51:127-128.

Doležel, J., J. Greilhuber, S. Lucretti, A. Meister, M. Lysak, L. Nardi \& R. Obermayer 1998. Plant genome size estimation by flow cytometry: inter-laboratory comparison. Annals of Botany 82:17-26.

Doležel, J., J. Greilhuber \& J. Suda 2007. Estimation of nuclear DNA content in plants using flow cytometry. Nature Protocols 2:2233-2244.

Farrell, L. 1985. Biological flora of the British Isles, No 160. Orchis militaris L. Journal Ecology 73:1041-1053.

Jacquemyn, H., R. Brys, O. Honnay \& I. Roldán-Ruiz 2012. Asymmetric gene introgression in two closely related Orchis species: evidence from morphometric and genetic analyses. BMC Evolutionary Biology 12:178.

Krasnikov, A.A. 2004. Methods of preparation of squashed samples for counting the plant chromosomes. In: Problems of karyology, karyosystematics and molecular systematics of plants, vol. 3 (A.A. Krasnikov, ed.), pp. 5-8, CSBG, Novosibirsk (in Russian) [Красников А.А. 2004. Методы приготов ения Аав еных препаратов Аля подсчёта хромосом растений / / Проблемы кариологии, кариосистематики и молекулярной систематики растений. Новосибирск: ЦСБС. Т. 3. С. 5-8].
Leitch, I.J., I. Kahandawala, J. Suda, L. Hanson, M.J. Ingrouille, M.W. Chase \& M.F. Fay 2009. Genome size diversity in orchids: consequences and evolution. Annals of Botany 104(3):469-481.

Rewers, M., I. Jedrzejczyk, A. Rewicz \& A. Jakubska-Busse 2021. Genome size diversity in rare, endangered and protected orchids in Poland. Genes 12:563.

Shamigulova, A.S. 2012. Features of biology, ecology and dynamics of coenopopulations of Orchis militaris L. in the steppe zone of the Bashkir Trans-Urals. Theses of dissertation ... cand. biol. science 03.02.01 - botany (in Russian) [Шамигулова А.С. 2012. Особенности биологии и экологии, Аинамика ценопопуляций Orchis militaris L. в степной зоне Башкирского Зауралья. Автореф. Аис... канА. биол. наук. 03.02.01 - ботаника. 2012 г.].

Soltis, D.E., P.S. Soltis, M.D. Bennett \& I.J. Leitch 2003. Evolution of genome size in the Angiosperms. American Journal of Botany 90:1596-1603.

Trutnev, Y.P. (ed.) 2008. Red Data Book of the Russian Federation: Plants and fungi. KMK Press, Moscow, 855 pp. (in Russian). [Красная Книга Российской Федерации (растения и грибы) / под реА. Ю.П. Трутнева. 2008. М.: КМК - Товарищество научных изданий. 855 с.].

Vakhrameyeva, M.G., M.N. Zagulskiy \& T.M. Bychenko 1995. Military orchid. In: Biological flora of Moscow Region (V.N. Pavlov \& V.N. Tikhomirov, eds), pp. 64-74, Izdatel'stvo MGU \& Argus, Moscow (in Russian). Вахрамеeва М.Г., Загульский М.Н., Быченко Т.М. 1995. Ятрышник шлемоносный // Биологическая флора Московской области / под реА. В.Н. Павлова и В.Н. Тихомирова. М.: ИзА-во МГУ, Аргус. Т. 11. С. 64-74].

Zaitsev, G.N. 1984. Mathematical statistics in experimental botany. Nauka, Moscow, 424 pp. (in Russian) [Зайцев Г.Н. 1984. Математическая статистика в экспериментальной ботанике. М., Наука, 424 с.]. 